was made. In the moanwhile, one must be grateful for the excellent account here given.

\section{The First Forty Years of the Royal Society of London}

AN exhibition has been arranged at the Science Musoum to illustrate the first forty years of the Royal Society of London. The exhibition is mainly biographical, and illustrates the seientific life and work of some twenty men, who were distinguished Follows during the period 1660-1700. The exhibits consist of a collection of portraits (enlarged photographs of engravings), copies of the Fellows' scientific publications, photographs of early documents of the Society, and a small collection of instruments and apparatus.

\section{British Men of Science}

To coincide with the tercentenary of the Royal Society, the preparation of a new series, British Men of Science, is announced by Nelson under the general editorship of Sir Gavin de Beer. The series will be designed to provide authoritative but short lives, written by leading scientists and intended for the general reader and university student. So far, twelve volumes are in preparation, but others are being actively planned. They are: "Joseph Black", by Prof. Douglas McKie; "Charles Darwin", by Sir Gavin de Beer ; "Humphry Davy", by Sir Harold Hartley; "Edmond Halley", by Sir Harold Spencer Jones; "William Gilbert", by N. H. de V. Heathcote; "William Herschel", by Angus Armitage; "Charles Lyell", by Sir Edward Bailey; "William Henry Perkin", by Prof. John Read; "Joseph Priestley", by F. W. Gibbs ; "Ernest Rutherford", by Sir Ernest Marsden; "Michael Scot", by Prof. Lynn Thorndike; "Joseph John Thomson", by Sir George Thomson. The series, which will be fully illustrated, is to be in line and half-tone and will contain a list of books for future reading.

\section{"Non-Enzymic Reactions of Indoles with Coen- zyme I"}

Prof. S. G. A. Alivisatos, G. A. Mourkides and A. Jibril write: "In a previous communication (Nature, $186,718 ; 1960)$ we described certain interactions occurring between indoles and coenzyme I. While recent evidence obtained in our laboratory with a number of other indoles and with the reduced form of coenzyme I confirmed our original observations, pointing towards an interaction of the indole with the nicotinamide moiety of the oxidized form of coenzyme $I$ (probably, a charge transfer complex), the proviously reported decrease in absorbancy observed in the ultra-violet region below $310 \mathrm{~m} \mu$ was lator shown to be an artefact produced by stray light when one of the reactants was present at high concentration in tho blank".

\section{Announcements}

Prof. P. B. Medawar, C.B.E., F.R.S., Jodrell professor of zoology and comparative anatomy at University College in the University of London, has been appointed director of the National Institute for Medical Research, Mill Hill, London, as from August 1962. Prof. Medawar succeeds Sir Charles Harington.

THE following have been elected honorary members of the American Institute of Nutrition : Lord Boyd Orr, Drs. W. A. Aykroyd, F. B. Berry, F. R. Boud- reau, R. C. Burgess, F. W. Clements, Dr. D. P. Cuthbertson, V. N. Patwardhan, Prof. E. F. Terroine and Prof. A. I. Virtanen. This is the first occasion on which the Society has elected honorary members.

Dr. J. H. Gerber has been appointed director of the Center for Aging Research of the National Institutes of Health, U.S. Department of Health, Education and Welfare, in succession to Dr. G. Halsey Hunt, who is now chief of the Division of General Medical Sciences, of which the Center is a component.

Dr. J. J. Gilman, of the Research Laboratory, General Electric Co., Schenectady, is to givo a lecture on "The Physical Nature of Plastic Flow", under the auspices of the Metal Physics Committee of the Institute of Metals. The meeting will be held at the Institute's headquarters, 17 Belgrave Square, London, S.W.1, on Tuesday, August 16, and from which further information can be obtained.

The Belgian Society of Pharmaceutical Sciences is organizing an International Symposium on Chromatography in Brussels during September 16-17. Further information can be obtained from the Bolgisch Genootschap voor Pharmaceutisches Wetenschappen, 11 Archimedesstraat, Brussels 4.

The Universities Federation for Animal Welfare is holding a Summer Congress at Culham College, Abingdon, Berks, during Septomber 16-22. Further information can be obtained from UFAW (Summer Congress), $7 a$ Lamb's Conduit Passage, London, W.C.l.

A NON-RESIDENTIAL summer school on "Numerical Analysis" will be held in Oxford during September 26-October 7. The object of the courso is to teach the elements of numerical analysis in the fields of linear algebra and differential equations to users of automatic digital computers in industry, government and university departments. Further information can be obtained from the Secretary to the Delegacy for Extra-Mural Studies, Rewley House, Wellington Square, Oxford.

THE fifth International Instruments and Measuremenis Conference and Exhibition are to be $h$ sld in Stockholm during September 10-17. The Conference is organized by tho Royal Swedish Academy of kngineering Sciences and tho Swedish Association of Tochnical Physicists. Further information concerning the British participation can be obtained from the Chief Press Officer, U.K. Atomic Enorgy Authority, 11 Charles II Street, London, S.W.1.

THE first British Congress on "The History of Medicine and Pharmacy" is to be organized by the Faculty of the History of Medicine and Pharmacy at the Worshipful Society of Apothecaries of London, in co-operation with the Royal Colloges and the Royal Society of Medicine, and held in London during September 29-30. Further information can be obtained from Dr. F. N. L. Poynter, Wollcome Historical Medical Library, The Wellcome Building, Euston Road, London, N.W.I.

As from July 31, the Imperial College of Tropical Agriculture is to bo merged into the University Colloge of the West Indies, and the Colloge will bo known as the University College of the West Indies, Faculty of Agriculturo (Imperial College of Tropical Agriculture), Trinidad, West Indies. The London office of the College is to be closed as from August 31 . 